also alarm individual patients as opposed to the general public.

I hope that this disagreement over a matter of adequate patient care will now cease and that the CCHMS will feel able to support the HJSC in its determination to ensure that the regulations are properly enforced for the benefit of students and patients alike.

\section{AUBREY BRISTOW} Chairman, Negotiating Committee
Hospital Junior Staff British Medical Association, London WC1H 9JR

SIR,-Thank you for giving me the opportunity to respond to Dr Aubrey Bristow's letter about the employment of medical students as locums for preregistration house officers.

I fully accept that Dr Bristow did not seek the attention of the media, but he embraced his opportunities for maximum publicity with an enthusiasm which caused great offence to many of the people I represent, particularly because many of the matters to which he referred were unauthenticated. The concept of verdict first and trial afterwards may be familiar to readers of Alice in Wonderland, but the use of the natural anxieties of patients as a weapon to achieve a political purpose is, in my view, totally unacceptable.

I am not "upset that the Hospital Junior Staff Committee is trying to uphold the regulations." I, too, am concerned that the regulations should be precisely followed when students are employed as locums. Such issues, however, are not appropriate to the HJSC or the Central Committee for Hospital Medical Services as they clearly fall within the remit of the Joint Consultants Committee, which is concerned with all matters affecting the standard of care offered in NHS hospitals. I have asked the chairman of that committee to raise the subject with the Chref Medical Officer and have no doubt that itwill be dealt with effectively. I hope that public discussion can now cease pending the outcome of the deliberations in the JCC.

\section{DAVID BOLT} Central Committee for Hospital Medical Services

British Medical Association

London WC1H 9JP

\section{Points}

\section{Multiple sclerosis and high pressure oxygen}

Dr David PerRins (Hyperbaric Unit, Rosenlunds Sjukhus, 11669 Stockholm, Sweden; writes: Dr Alan Turner must have written his annotation on high pressure oxygen and multiple sclerosis (19 March, p 967) before the publication of the randomised, placebo controlled, double blind study by Fischer et $a l,{ }^{1}$ in which 12 of 17 patients treated with hyperbaric oxygen showed objective improvement but only one of 20 controls. Those of us who have witnessed such improvement, occurring within a few days of the onset of treatment, are confident that the multicentre trial now being conducted will confirm these preliminary results. Whether the treatment induces significant long term improvement is still unknown.

Fischer BH, Marks M, Reich T. Hyperbaric oxygen treatment of mult

\section{Amniotic band syndrome}

Mr Graham H Barker (Central Middlesex Hospital, London NW10 7NS) writes: Dr D I Rushton (19 March, p 919) omitted to mention the association between amniotic bands and the ingestion of lysergic acid diethylamide (LSD) in pregnancy. ${ }^{1}$ If such an association exists it would be sensible to exclude this when counselling patients for a subsequent pregnancy. I wonder if any reader has had experience of LSD abuse causing amniotic bands.

'Blanc WA, Mattison DR, Kane R, Chauhan P. LSD,
intrauterine amputations, and amniotic band syndrome. Lancet 1971 ; ii:158-9.

\section{One man's burden}

Dr S L LAST (Wingrave, Aylesbury HP22 4PL) writes: I think Dr Michael O'Donnell is making rather heavy weather of Alison's wax in her ear (26 March, p 1067). Some years ago I visited a friend who was a distinguished scientist and who, according to his wife, was being treated by a specialist for thyroid disease (?deficiency). During dinner it became obvious to me that my friend had Parkinson's disease with little tremor. I hesitated for a time but eventually advised him that I thought he should consult a neurologist. When asked why, I told the truth. I did not tell them how to go about it. A neurologist was consulted and for a number of years my friend's condition was relieved by appropriate treatment. It seems to me that my way of dealing with it was in the patient's interest and did not offend my colleagues.

\section{Student electives in Papua New Guinea}

Ms Lindsay CORRIE and $\mathrm{Mr}$ Adrian J TRELOAR (Guy's Hospital Medical School, London SE1 9RT) write: We have both recently had our applications for electives in Papua New Guinea rejected. In one case the recent article by Dr M Kurer 18 September, p 793) was cited as the only reason for present hostility felt by Papua New Guineans towards students and for the rejection. We hope that it will be remembered in future that articles such as Dr Kurer's, which was bound to offend and insult health workers in Papua New Guinea, will necessarily spoil the marvelous educational opportunity of electives there for future students.

\section{ABC of healthy travel}

Dr Tony Chapman (Durham DH7 9HD) writes: Dr Eric Walker and Dr Glyn Williams repeat the contraindication listed by the manufacturers of anticholinergic drugs such as hyoscine (Kwells) for those suffering from glaucoma (12 March, $p$ 865). This is an unnecessary restriction because the only travellers who would suffer would be those in whom acute angle closure glaucoma had not yet been diagnosed. A patient who had suffered a previous attack would have had a drainage operation, normally to both eyes, and this would remove further risk. Patients suffering from chronic simple (open angle) glaucoma are not at risk before or after diagnosis. Theirs is a pathologically and clinically quite distinct condition, in which anticholinergic drugs do not have untoward side effects.

\section{Non-hormonal treatment of osteoporosis}

Dr M KeITh Thompson (Woodside Health Centre, London SE25) writes: Dr Allan St J Dixon (26 March, p 999) states that the most informative studies on osteoporosis have been on women who have undergone bilateral oophorectomy because the "date of the menopause is known." May I respectfully point out that he has fallen into a common but cardinal error in referring to castration as the menopause. Although both may be followed by osteoporosis the physiology of the two processes is quite different.

\section{Hyponatraemia and hypernatraemia in} children with acute diarrhoea

Dr S Margaret FaRquHarson (Basingstoke District Hospital, Hants) writes: I was interested in the association of hyponatraemic dehydration with malnutrition and a poor prognosis reported by $\mathrm{Dr} A \mathrm{R}$ Sanadi and others (26 February, p 671). The explanation of the poor reserves of electrolytes in malnourished children predisposing to hyponatraemia is valid only if the hyponatraemia is associated with a low total body sodium. In the malnourished patient after operation a low serum sodium concentration is often seen but in association with a raised total body sodium and a shift of fluid and electrolytes from the intravascular compartment. This is also associated with a high mortality and is more effectively treated with intravenous feeding than with sodium infusion to correct serum sodium concentration. Could a similar mechanism explain the hyponatraemia in malnourished infants with diarrhoea?

\section{High calorie supplements for patients with anorexia nervosa}

Dr Michael A Launer (Department of Psychological Medicine, Burnley General Hospital, Burnley, Lancs BB10 2PQ) writes: With reference to my letter in the $B M \mathcal{F}$ (26 February, p 723) I have received a communication from the Department of Health and Social Security informing me that they had wrongly added Forceval Protein to the list of supplements that can now be prescribed for anorexia nervosa.

\section{Correction}

\section{Erythrapheresis in polycythaemia}

We regret that an error occurred in the letter by Dr R J Gregory (26 March, p 1056). The third sentence should have read: " ".. a raised packed cell volume (or haemoglobin) from whatever cause is associated with an increased morbidity and mortality." 